PAEDIATRIC LESSONS FROM THE PAST

\title{
Physician, philosopher, and paediatrician: John Locke's practice of child health care
}

\section{A N Williams}

Arch Dis Child 2005;91:85-89. doi: 10.1136/adc.2005.078162

G.F. Still's History of Paediatrics restricted the philosopher John Locke's (1632-1704) influence in paediatrics to pedagology and specifically his Some Thoughts Concerning Education (1693).' This significantly limits Locke's immense ongoing influence on child health care and human rights. Locke was a physician and had a lifelong interest in medicine. His case records and journals relate some of his paediatric cases. His correspondence includes letters from Thomas Sydenham, the "English Hippocrates" (1624-89) when Locke has sought advice on a paediatric case as well as other correspondence from parents regarding child health care and management of learning disability. Locke assisted and influenced Thomas Sydenham with his writing, and Locke's own work, Two Treatises on Government, clearly stated the rights of children and limitation of parental authority. Furthermore, Locke's thoughts on Poor Law, making an economic case for a workhouse in every parish, were implemented from 1834.

Correspondence to: Dr A N Williams, Child Development Centre, Northampton General Hospital, Northampton NNI 5BD, UK; anw@ doctors.org.uk

Accepted 20 June 2005
J ohn Locke is remembered now as the most influential philosopher of modern times. ${ }^{2} \mathrm{He}$ was the author of An Essay Concerning Human Understanding (1689), regarded as the foundation of the Enlightenment in the eighteenth century, ${ }^{3}$ and which "ushered in the modern world of ideas". ${ }^{4}$ This has almost completely overshadowed the fact that Locke studied medicine throughout his lifetime, practiced as a physician, and whose own medical opinion was generally held in high regard. Sir William Osler praised Locke thus: "No member of our profession of any age or any country has made so many important contributions to philosophy and practical politics as Dr Locke". ${ }^{5}$

\section{LOCKE'S EARLY LIFE}

John Locke (fig 1) was born in Wrington, Somerset on 29 August 1632 and baptised the same day. In 1646 he started at Westminster School, London (becoming a King's Scholar in 1650), and in 1652 entered Christ Church, Oxford, receiving his BA degree in 1655 and his $\mathrm{MA}$ in $1658 .^{6}$

Locke continued as Fellow at Christchurch, Oxford and was also one of the celebrated virtuosi working with Robert Boyle and Robert Hooke, among others. Richard Lower (1631-91), who performed the first successful blood transfusion, persuaded Locke to study medicine, and Locke attended the lectures delivered by Thomas Willis (1621-75) in Oxford sometime in 1664/1665. Locke's notebooks reflect the lecture and the experiments of the age, and can still be a source of illumination. ${ }^{7}$

In 1665 Locke was appointed secretary to the diplomatic mission of Sir Walter Vane. He returned in 1666 and became an assistant to an Oxford physician, Dr David Thomas. That year Locke met a rising politician, Lord Ashley (later Lord Shaftesbury), who was greatly impressed with Locke's medical knowledge and they became friends.

Locke continued to study medicine and unsuccessfully applied for a dispensation for a DM degree in 1666 and 1670. He finally received his BM degree on 6 February 1675 after having fulfilled the academic conditions.

In 1667 Locke became personal physician and member of the household of Lord Shaftesbury, moving into political exile with him in 1675. Locke's life was thereafter punctuated by long periods abroad but he maintained contact with friends, including Thomas Sydenham and kept an active interest in medical matters throughout his life.

Indeed as late as 1677 Locke still had hopes of a medical appointment, the Gresham professorship, but this came to nothing. Although Locke still continued to have an interest in medicine, his subsequent efforts became directed more towards philosophy and politics. Following the Glorious Revolution of 1688, Locke's political circumstances considerably improved and he returned from exile in 1689. He then published the philosophical and political works for which he is now remembered. He was also appointed a Commissioner of the Board of Trade, his duties including the formulation and administration of government economic policy. ${ }^{8}$

Throughout his life, Locke's health was blighted by asthma, which often incapacitated him for long periods.

He never married nor had any children. His last years were in Oates at the home of Sir Frances and Lady Marsham in Essex. He died there on 28 October 1704.

\section{JOHN LOCKE'S PAEDIATRIC PRACTICE}

Up to 1667, there is no evidence that Locke treated any identifiable patient. ${ }^{9}$ Locke's main duties were non-medical in Lord Shaftesbury's house and he practiced infrequently or when his opinion was asked. In spite of this limited practice, Locke developed a strong reputation as a physician. His letters and journals show that he 


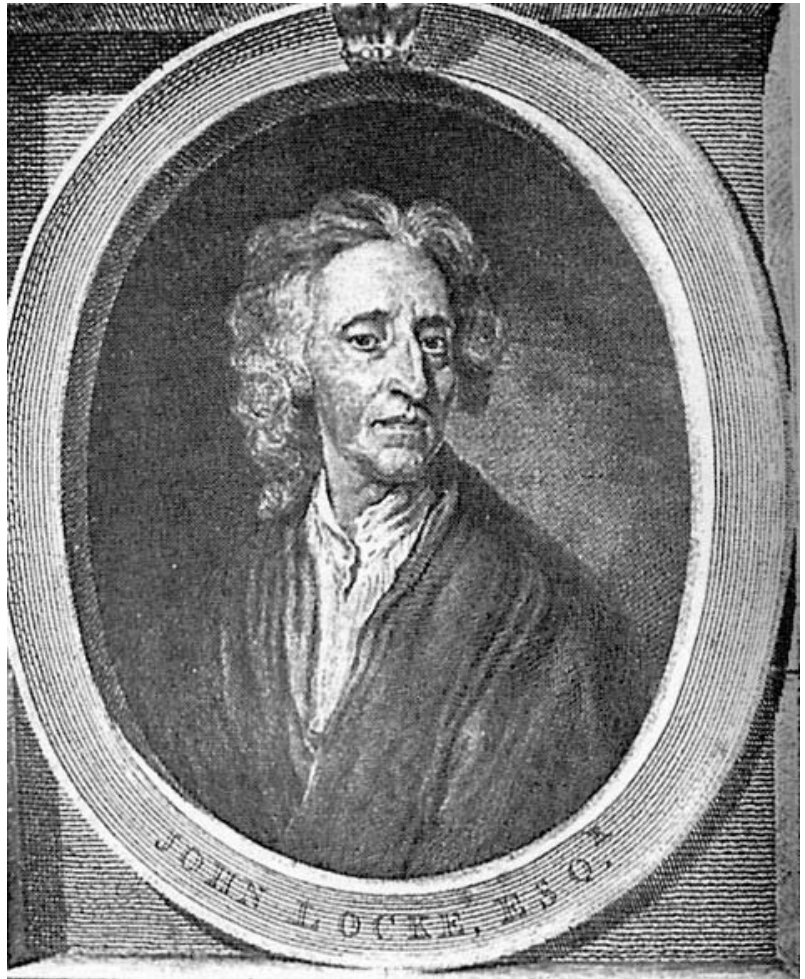

Figure 1 John Locke's portrait, reproduced with kind permission from the RCPCH.

was often consulted on a variety of medical subjects, seeing patients of both sexes and all ages.

Sometime in 1667 John Locke met Thomas Sydenham and embraced his medical ideas. Both held the other in high regard and Locke helped Sydenham with writing his works. Sydenham described Locke as having "few equals and no superiors". ${ }^{10}$ Locke in turn described Sydenham as "that Great Genius of Physick". ${ }^{10}$ In 1669 Sydenham and Locke collaborated in writing De Arte Medica, but this was never completed.

Seeing children when required to, Locke did not make discoveries relating to paediatric disease or practice, and his treatments reflect the practice of the age and in particular the influence of Sydenham.
Box 1: Selection of Locke's notes on his treatment of William Sydenham

Measles. March 7th 1670. W. Sydenham, a boy aged 11 years of a delicate constitution, with lungs naturally weak and very liable to cough, was taken with a shivering and rigor, followed by a slightly raised temperature, defluxion, somnolence, cough, anorexia.

Sixth day. The whole face was discolured by red spots of irregular shape, composed of very minute red papules slightly raised above the surface and causing a roughness of the face perceptible to the touch... Treatment, refrigerant, out of bed, drink barley water.

Ninth day. Spots gone from the whole body. Temperature normal...Treatment as before.

Twelfth day. ....cough worse and a facies Hippocratica. In the evening he was bled $60 z$, whence the cough diminished the same night. $^{13}$

\section{ANTENATAL CARE}

In 1671 Locke successfully managed the pregnancy of Lady Dorothy Ashley Cooper, in spite of a threatened miscarriage, and she was safely delivered of a boy. The maternal grandmother, Lady Rutland wrote to Locke, thanking him:

"The Lords name be blest and praised for her well doeing, and safely bringing that noble familie so hopefull an heir, that early accosts ladies in bed and manages a weapon at 3 days olde to my wonder and joy." ${ }^{\prime \prime 1}$

\section{WILLIAM SYDENHAM}

Recorded in his 1670 Observationes Medicae, Locke attended Thomas Sydenham's 11 year old son William for measles. Thomas Sydenham is of course remembered for having made "the most minute and careful description of measles which had yet appeared". ${ }^{12}$ Locke's description is no less minute (regarded by Osler as being very complete, giving observations over 13 days $\left.{ }^{5}\right)$. Selected highlights are given in box $1 .{ }^{13}$

Although it is a mark of the considerable respect Locke was held in by Sydenham that he allowed his own son to be treated by Locke, it should be noted that Locke advocated for measles Sydenham's own method of "Regimen: refrigerans, surrectio, potus aqua hordei"14 translated in terms of

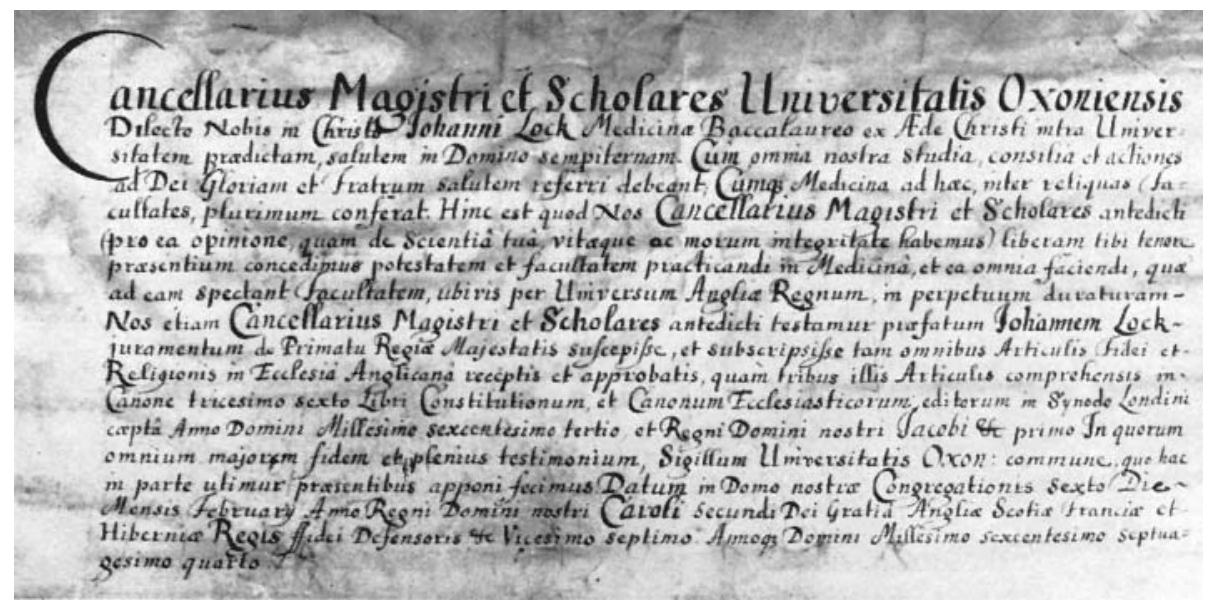

Figure 2 Locke's Medical Licence from the University of Oxford, 6 February 1675, reproduced with kind permission from the Bodleian Library, University of Oxford. 


\section{Box 2: Locke's treatment of Penelope Hunt}

1668

Inflammatory fever. June 16th, Penelope Hunt, aged 4 years, was seized with a burning fever, with a bright redness of the cheeks, neck, chest and whole body. She felt pain on pressure in the region of the ensiform cartilage: tongue much whitened, pain and inflammation of the fauces, an eruption of very small papules over the skin.

Take water of purslain, water and parsley, each four oz; cinnamoni hordeati, one oz; syrup of violets and lemon, each one and a half oz. Mix: make a julep, of which let her take three or four oz every three hours.

Take decoction of cinnamon for a clyster, four oz; red sugar and syrup of vilets, each one oz. Mix: make a clyster to be injected tomorrow morning. From which she had one motion with much flatus and relief.

June 17th. The fauces were painful and the tongue white. Take water of plantain, roses and prunella, each one and a half oz; syrup of raspberries... Oil of vitriol sufficient to produce very slight acidity. Mix make a gargle. She recovered within three days. ${ }^{13}$

therapeutic practice as "cooling, getting up and about, with plenty of barley water".

\section{PENELOPE HUNT}

Another case is that of Penelope Hunt, a 4 year old girl with "inflammatory fever" which we can speculate may have been scarlet fever (box 2). Locke's treatment was based on the Galenic principles of balancing the humours.

\section{LOCKE'S MEDICAL JOURNALS: CALEB BANKS}

In August 1678 Locke was urgently recalled from France by Sir John and Lady Banks to treat their son (a former pupil), Caleb Banks, who was ill with fever. Locke's journal records the boy's condition mainly presenting with fever and occasional rigors.

Sun, August 24th. C.B. sweat by fits a great part of the day but without any relief. Driness of tongue and weakenesse and quickness of pulse returning as soon as the sweat is over. $^{15}$

Locke's treatment used the Cinchona bark (quinine and still a secret remedy at that time) and it did not initially work. So Locke wrote to Thomas Sydenham for advice. Sydenham replied twice. In the first letter (30 August) he advised Locke to repeat the Cinchona treatment, and in the second letter (6 September) emphasised that Locke must persevere with it (box 3).

However, Sydenham's second letter proved unnecessary; by 5 September Locke recorded that Caleb Banks had made a recovery. ${ }^{15}$

As a general principal Locke disliked treating patients by post and constantly advised his correspondents to see their local practitioner, although he would often give advice regarding prescriptions.

\section{EDWARD CLARKE AND "SOME THOUGHTS CONCERNING EDUCATION"}

There are many instances in Locke's correspondence where is advice is sought concerning the education of his friends' children. ${ }^{17}$ (One example is a letter from Lord Shaftesbury thanking Locke for his educational advice in 1680.) This, and
Box 3: Thomas Sydenham's second letter to

Locke regarding this case

Sept. 6, 1679

Dear Sir,

Had you observed the counsel which I gave you your patient had by this time been free from the symptoms of dejection of appetite, weakness etc which you mention. Nor can there be a more expeditious way thought upon to procure his health and your dismission than the giving the $\mathrm{C}$ (Cortex peruvianus - quinine) as I prescribed: and it must still be done for if he have his fitts with what else can you put them away? If he have not them, how else can you prevent their returne, which will certainly happen without the repeating of this medicine every week for two or three weeks longer-he having been reduced to so great a weakness of blood ?...

I am entirely,

Yours

$\mathrm{T}: \mathrm{S} .{ }^{16}$

particularly correspondence concerning Edward Clarke (the son of Locke's cousin), later led to his celebrated Some Thoughts Concerning Education (1693) which detailed plans for the education of a Gentleman. The correspondence about Edward's Clarke's education commenced in 1684 when it is clear his father already had some concerns regarding his then 8 year old son.

However, two years later Edward Clarke became very unwell as his father's (also called Edward) letter attests (box 4).

Locke's reply fully supports Sydenham and he adds a guarded prognosis:

"In the meantime I know not what to say, for I conclude before this comes to your hand the child's disease will be some way or other concluded." ${ }^{\prime 19}$

Given the history of family members having an infection of some kind just before, one could speculate that Edward suffered from a possible viral encephalitis, but one cannot exclude a chronic fatigue syndrome.

Edward made a slow recovery and subsequent letters over the years related the ongoing quest of Edward Clarke's parents to find a tutor to help with his persisting educational difficulties. Five years later, in 1691, Locke assessed Edward and wrote the following report:

"I am satisfied about your son that he wants not parts, so that if he has not made all the progress we could have desired I lay it wholly upon want of application. ${ }^{\prime 20}$

Locke considered a French tutor but departed from his own doctrine of education:

\section{"...or else perhaps I might advise you to [send him] to Westminster or some other very severe school, where if he were whipped soundly whilst you are looking out another fit tutor for him, he would perhaps be more pliant and willing to learn at home afterwards." 20}

Unfortunately, there appears to have been no resolution and in 1699, when Edward was 23, he suffered a severe bout of depression as he clearly recognised he was not able to meet his family's expectations. Now we understand that following 


\section{Box 4: Letter from Edward Clarke to Locke}

London, November 25th 1686

Dear Sir,

Soon after the writeing of my last of the 5th instant to you, my Wife and your little Mistris were seised with violent Colds and before they were perfectly Recovered, my Eldest son fell ill of a violent Feaver, which in 3 or 4 dayes time, (Notwithstanding all the Indeavours of Doctor Sydenham and Doctor Goodall to the contrary) gott soe into his head that Hee has layne ever since (this being now the 13th day since Hee was taken ill) in a Doz'd and sleepy condition, and hath taken nothing but of theire Prescribing, and is now reduc' $d$ to a verie greate degree of weaknesse without the least appearance of amendment, and what the Event will bee God only Knows: I... heartily wish it were possible for mee to have your Assistance, but since that cannot bee, I shall acquiess in what they doe, and pray God to give a Blessing to their indeavours, and restore the Child to his former health and understanding. ${ }^{18}$

serious intracerebral illness or injury, children can take many years to "grow into" their full deficits or that psychiatric disorders can be co morbid with chronic fatigue syndrome. ${ }^{21}$ Interestingly Locke ascribed "the cause of that despondency" solely to an organic cause, the events of 1686, and surprisingly completely discounted the possibility of a psychological explanation. ${ }^{22}$

One cannot help sympathising with Edward Clarke, who by 1699 was all too aware of his educational limitations and his inability to overcome them.

\section{LOCKE AND HUMAN RIGHTS}

Modern child health care is built on the foundations of medical science and children's rights. Locke's ongoing relevance is that in Two Treatises of Government (1690) he was one of the first to postulate that men had basic rights. ${ }^{23}$ (Locke wrote this treatise to counter Sir Robert Filmer's Patriacha (1680) which postulated there were no limits to a king's authority.) Locke's argument was equally specific regarding the equal rights of both parents and set limits to what is morally permissible in how parents treat their children condemning infanticide and cruelty to children. Locke then emphasised how these limits change as the child matures to adulthood and was clear that once childhood has passed, mutual obligations cease and both child and parents are equally free. Locke also recognised that there are those who will remain forever under the "government of their parents" and includes both lunatics and idiots within this group.

In Section 58 Locke emphasises the positive nature of parental duty:

\footnotetext{
"The power, then, that parents have over their children arises from that duty which is incumbent on them, to take care of their offspring during the imperfect state of childhood. To inform the mind, and govern the actions of their yet ignorant nonage, till reason shall take its place and ease them of that trouble, is what the children want, and the parents are bound to." 24
}

Locke's writings regarding rights of man and the obligations of society are one of his most profound and lasting influences on the thoughts of present day society. Their past and ongoing present influence cannot be understated, being the intellectual foundation on which the Enlightenment of the eighteenth century was built. ${ }^{3}$ Locke's writings predate the first Declaration of the Rights of a Child drafted by the League of Nations in 1924 and the Convention on the Rights of the Child adopted by the United Nations in 1989. ${ }^{25}$

The debate regarding Locke and rights, and children's rights in particular goes far beyond this cursory introduction. Of course it is still very much ongoing, extending beyond the issues of nurturance verses self-determination, even to debating the extension of voting to children. ${ }^{26}$

\section{LOCKE AND THE LAWS OF CAROLINA (1669)}

In this constitution which Locke drew up (but which was never enacted), Locke wrote a statute to create a registry of births, marriages, and deaths, non-compliance being punishable by a fine of "one shilling per week for each such neglect, reckoning from the time of each birth, or death, respectively, to the time of registering $\mathrm{it}^{\prime \prime} .^{27}$

Nowadays it would be inconceivable for any state not to keep an ongoing register of its citizens. Although Locke was merely following the ideas of Sir William Petty, nevertheless he showed clear foresight in placing this as a constitutional statute. Registration of all births, marriages, and deaths became compulsory in the United Kingdom, more than a century after Locke's death, in 1837.

\section{LOCKE AND HIS THOUGHTS ON PAUPER CHILDREN}

Locke was a member of the Board of Trade, and one of the areas he considered in 1697 was pauperism, a perennial problem. In a submitted paper Locke proposed a scheme to the Board of Trade, which was rejected. For children he suggested that pauper schools be established in every parish where mothers and children could work productively. Locke suggested that they should have:

"a bellyful of bread daily...and to this may be added,
without any trouble, in cold weather, if it be thought
needful, a little warm water gruel for the same fires that
warms the room may be made use of to boil a pot of it."

Locke calculated that:

"computing all the earnings of a child from three to fourteen years of age, the nourishment and teaching of such a child during the whole time will cost the parish nothing instead of the $£ 50$ or $£ 60$ such pauper children cost their parishes under existing poor law schemes. ${ }^{\prime 28}$

Locke's shocking scheme was rejected but was later implemented with the Poor Law Reforms of 1834. Readers of the works of Charles Dickens will be well aware of the consequences of Locke's ideas in this case being put into practice. It should be noted firsty, however, that the Poor Law Commissioners of 1835 ignored, on the grounds of cost, the recommondation of 1834 that destitute school aged children should be provided entirely separate institutions under schoolmasters. Secondly, that Locke himself is recorded by his contemporaries as being "naturally compassionate and exceedingly charitable to those in want". ${ }^{29}$ One could therefore reasonably speculate that Locke too would have been appalled by the conditions of children within the workhouse system.

\section{CONCLUSION}

It is clear that John Locke's influence is far greater than that of education alone as described by Still. Locke had an excellent reputation as a physician, was frequently consulted, and although infrequently practiced, treated some children including Thomas Sydenham's son as well as consulting with Thomas Sydenham on cases. 
Locke's medical influence, especially through working with Thomas Sydenham, is equally profound. William Osler presciently stated: "we may claim Dr Locke as a bright ornament of our profession, not so much as what he did in it, as for the methods which inculcated and the influence which he extended upon the English Hippocrates". ${ }^{5}$

We can wonder, like Stills, as to where Locke had had time to make his observations as he had no children of his own and was tutor to only a few children within his lifetime.

John Locke's medical writings are overshadowed when compared to his other writings. Indeed philosophers concentrate on Locke's influence being in two main areas: his empiricist theory of knowledge and his commitment to the inalienable rights of all human beings. ${ }^{30}$ Roy Porter saw Locke as the key to the eighteenth century ideas that became prevalent. $^{3}$

The Duties of a Paediatrician within the statutes of the Royal College of Paediatrics of Child Health enshrine what are perceived to be the essential qualities and attributes for a practitioner in paediatrics. ${ }^{31}$ Locke treated children, was asked his opinion about them, and through his writings on Children's Rights, Education, and Poor Law reform, advocated for them. Of course John Locke was not a paediatrician in the modern sense that we understand it. Nevertheless, through his practice and writings Locke embraced the tenets of this specialty and directly led to its recognition and current stature. In particular Locke was one of the first to proclaim children's rights.

On Poor Law, only the implementation of his ideas in 1834 would show how wrong they were. The workhouses he advocated are still held in living memory and the State has taken a different path to support its "paupers".

Thus as both a philosopher and a physician, Locke still continues to immensely influence philosophical debate as well as the issue of human rights through his philosophical writings and medical practice, and through his influence on Thomas Sydenham. Perhaps the final word should be left to Locke and Sydenham with an except from their unpublished De Arte Medica of 1669:

"It is idle to expect any great advancement in science from the superinducing and engrafting of new things upon old. We must begin anew from the very foundations, unless we would revolve for ever in a circle with mean and contemptible progress. ${ }^{\prime 32}$

\section{ACKNOWLEDGEMENTS}

I would like to thank Dr Margaret Holloway, the British Museum, the Bodleian Library, the Centre for the History of Medicine, Birmingham and the Cripps Medical Centre, Northampton for their advice and support.

Competing interests: none declared

\section{REFERENCES}

1 Still GF. The history of paediatrics, 1931, republished by the College of Paediatrics and Child Health, 1996:317.

2 Aarsleff H. Chapter 10. Locke's influence. In: Chappell V, ed. The Cambridge companion to Locke Cambridge, Cambridge University Press, 1999:253.

3 Porter R. The greatest benefit to mankind. London: Harper Collins, 1997:243.

4 Wood N. The politics of Locke's philosophy. Berkeley, CA: University of California Press, 1983:1.

5 Osler W. John Locke as a physician. Lancet 20 October 1900:1116.

6 Meynell GG. A database for John Locke's medical notebooks and medical reading. Medical History 1997;42:473-86.

7 Williams AN. Too good to be true. Thomas Willis. Childhood stroke, neonatal convulsions and infanticide. Seizure 2001;10:471-83.

8 Ashcraft R. Chapter 9. Locke's political philosophy. In: Chappell V, ed. The Cambridge companion to Locke Cambridge, Cambridge University Press, 1999:244.

9 Milton JR. Chapter 1. Locke at Oxford. In: Rogers GAJ, ed. Locke's philosophy: content and context. Oxford: Clarendon Press, 1994:45.

10 Dewhurst K. John Locke, physician and philosopher. A medical biography. The Wellcome Historical Medical Library, 1963:41.

11 Dewhurst K. John Locke, physician and philosopher. A medical biography. The Wellcome Historical Medical Library, 1963:43.

12 Still GF. The history of paediatrics, 1931, republished by the College of Paediatrics and Child Health, 1996:277.

13 Withington ET. John Locke's medical observations. Medical Magazine 1898:375-87.

14 Withington ET. Locke as a medical practitioner. Janus 1899:21.

15 Dewhurst K. John Locke, physician and philosopher. A medical biography. The Wellcome Historical Medical Library, 1963:167-72.

16 Dewhurst K. Dr Thomas Sydenham (1624-1689). His life and original writings. Berkeley, CA: University of California Press, 1966:172-3.

17 Yolton JW, Yolton JS. Introduction. In: Locke J, ed. Some thoughts regarding education. Oxford: Clarendon Press, 1989:6.

18 Letter from Edward Clarke to John Locke. London, 25 November 1686. In: de Beer, ed. The correspondence of John Locke. Oxford: Clarendon Press, $1989 ; 111: 73$.

19 Letter from John Locke to Edward Clarke. 17 December 1686. In: de Beer, ed. The correspondence of John Locke. Oxford: Clarendon Press, 1989;111:74.

20 Letter from John Locke to Edward Clarke. 26 February 1691. In: Cranston M, ed. John Locke. A biography. London: Longmans, 1957:355.

$21 \mathrm{RCPCH}$. Evidence based guideline for the management of CFS/ME (chronic fatigue syndrome/myalgic encephalopathy) in children and young people. London: Royal College of Paediatrics and Child Health, December, 2004:90.

22 Lefter from John Locke to Edward Clarke. 28 April 1699. In: Cranston M, ed. John Locke. A biography. London: Longmans, 1957:443.

23 Porter R. Enlightenment. Penguin Books, 1997:185.

24 Locke J. Chapter VI. Two treatises of government, 1 st treatise "Of Adam, a title to sovereignty by fatherhood". In: The works of John Locke, Vol. V, 10th edn. London: T Davison, 1801:382.

25 UNICEF. Introducing the rights of the child. In: The Convention on the Rights of the Child. UNICEF, 1995:1.

26 Franklin B. The rights of children. Oxford: Basil Blackwell, 1986:17-19.

27 Locke J. The laws of Carolina. In: The works of John Locke, Vol. X, 10th edn. London: T Davison, 1801:192-3.

28 PRO Board of Trade. Papers c 30 f.94. In: Cranston M, ed. John Locke. A biography. London: Longmans, 1957.

29 Lady Marsham. Amsterdam: Remonstrants' MSS. J. 57a. In: Cranston M, ed. John Locke. A biography. London: Longmans, 1957:426.

30 Locke J. Introduction. In: An essay concerning human understanding. Penguin Classics, p.x.

31 RCPCH. The duties of a paediatrician. London: Royal College of Paediatrics and Child Health, 2005:xxxvi.

32 Shaftesbury Papers. Public Record Office, Bundle 47/2. In: Wood N, ed. The politics of Locke's philosophy. Berkeley, CA: University of California Press, 1983:68. 